\title{
PENGARUH PENDIDIKAN ISLAM TERHADAP KECERDASAN SPIRITUAL PADA REMAJA YANG TINGGAL DI LINGKUNGAN PEKERJA SEKS KOMERSIAL (PSK) TANAH ABANG JAKARTA PUSAT
}

\author{
Radhiya Bustan, Emmalia Sutiasasmita, Hanifah Arief \\ Program Studi Psikologi, Fakultas Psikologi dan Pendidikan, Universitas Al-Azhar Indonesia, \\ Jl.Sisingamangaraja, Jakarta 12110 \\ Lembaga Penelitian dan Pengabdian Masyarakat (LP2M) Universitas Al Azhar Indonesia
}

Email untuk korespondensi: radhiya_bustan@uai.ac.id

Abstrak - Pembentukan kepribadian anak-anak usia muda atau remaja sangat dipengaruhi oleh lingkungan tempat tinggal dimana mereka berada, seperti halnya terjadi pada remaja yang berada/tinggal di lingkungan Pekerja Seks Komersial (PSK), yang telah mempengaruhi pada identitas dirinya, dan kebanyakan telah menjadi pekerjaan turun - temurun dalam keluarga mereka. Terdapat satu kelompok Pengajian Hurin'in dalam lingkungan tersebut, yang berupaya memberikan pencerahan kepada para remaja dengan kegiatan pendidikan Islam, berupa: shalat, puasa, membaca al-Qur'an dan fiqih. Dan untuk mengetahui pendidikan Islam tersebut berpengaruh terhadap kecerdasan spiritual peserta didiknya, yang mencakup: makna, nilai, transenden, hubungan dan menjadi, maka dilakukan penelitian dari kegiatan pendidikan Islam, yang difokuskan pada tiga unsur: akidah (iman), ibadah (Islam), dan akhlak (ihsan), dengan menggunakan metode penelitian terhadap remaja santrinya dengan instrumen skala likert dari hasil angket sebagai tehnik pengumpulan data. Hasil penelitian memperlihatkan bahwa pendidikan Islam yang dilakukan selama ini di Pengajian Hurin'in berpengaruh terhadap kecerdasan spiritual pada remaja santri yang tinggal di lingkungan PSK, dengan hasil $\mathbf{4 5 , 3 \%}$ merupakan variabel kecerdasan spiritual. Dan kesimpulan berdasarkan seluruh analisis data yang dilakukan, menunjukkan bahwa seluruh aspek kecerdasan spiritual telah dapat dipahami oleh remaja peserta didik dan selanjutnya disarankan untuk dapat mempertimbangkan variabel lainnya, seperti pengaruh kepedulian sosial dan pola asuh orang tua.

Abstract - Formation of personality of young children or adolescents is influenced by the neighborhood where they are lived, as well as in adolescents who are / living in the Commercial Sex Workers (CSW), which has affected their identity, and most have been doing the job for generations in their family. There is one group called Pengajian Hurin'in in that neighborhood, which seeks to enlighten the youth with Islamic educational activities, such as: prayer, fasting, reading the Qur'an and fiqh. And to foud out if the Islamic education affects the spiritual intelligence of the students, which include: meaning, value, transcendence, and the becoming, a research of Islamic educational activities, which focused on three elements: Aqeedah (faith), prayer (Islam), and morals (ihsan), was conducted on the adolescent students using the method of research Likert scale instrument from the questionnaires as data collection techniques. The results showed that Islamic education is done so far in Pengajian Hurin'in affect spiritual intelligence in young students living in the neighborhood, with the result of $45.3 \%$ variable of spiritual intelligence. The conclusions based on all the data analysis indicates that all aspects of spiritual intelligence has been able to be understood by the young learners and are 
further advised to consider other variables, such as the influence of social and parental upbringing.

\author{
Keywords - Islamic Education, Spiritual \\ Intelligence, Teens, and Sex Commercial Workers \\ (PSK).
}

\section{PENDAHULUAN}

\subsection{LATAR BELAKANG}

$\mathrm{L}$ ingkungan tempat tinggal bagi setiap orang dimanapun dia berada, merupakan suatu dasar yang signifikan dalam pembentukan kepribadian orang yang berada di sekitarnya, khususnya dalam keluarga dan umumnya masyarakat sekelilingnya. Terlebih pengaruh itu akan lebih besar dampaknya kepada anak-anak usia muda atau remaja, yang mana sesuai dengan perkembangan dan dinamikanya saat itu, mereka sedang mencari jati diri dan pengakuan atas eksistensinya. Menurut Erikson dalam Hurlock (1980) berpendapat bahwa masa remaja merupakan masa mencari identitas. Identitas diri yang dicari remaja berupa usaha untuk menjelaskan siapa dirinya, apa perannya dalam masyarakat. Maka kemudian akan muncul pertanyaan apakah ia mampu percaya diri sekalipun latar belakang keluarga membuat orang merendahkannya? Atau akankah ia mengadopsi sikap dan perilaku orang-orang di lingkungannya? Mereka memerlukan bimbingan dan bantuan dari keluarga, guru, serta lingkungan dalam menguasai tugas perkembangan dan membentuk identitas diri yang ideal.

Berbagai upaya untuk membangun dan meningkatkan kualitas sumber daya manusia di dalam lingkungan masyarakat pada umumnya, saat ini telah dilaksanakan oleh berbagai lembaga, melalui berbagai program yang telah disiapkan, baik itu Lembaga Pemerintah maupun Swasta dan Lembaga-lembaga Sosial dengan sumber dana dari dalam dan luar negeri, bahkan Lembaga Pendidikan, yang mana secara keseluruhan tujuan utamanya adalah agar tercipta sebuah masyarakat madani yang didukung oleh kemandirian melalui penyerapan program yang telah disiapkan.

Melihat dinamika kehidupan di kota metropolitan Jakarta, yang mana didalamnya terdiri dari berbagai kepentingan, mulai dari politik, ekonomi, sosial, budaya dan agama serta lainnya, mengakibatkan terjadinya berbagai fenomena yang sangat beragam. Salah satu fenomena yang sangat menyentuh hati setiap orang yang melihat dan tidak banyak orang yang mau menyediakan waktu dan sarana/prasarana agar terjadi perubahan ke arah yang lebih positif, adalah lingkungan Pekerja Seks Komersial (PSK) Bongkaran Tanah Abang, dimana kehidupan malam yang telah berlangsung sekian lama dan kebanyakan telah menjadi pekerjaan yg turun temurun dalam keluarga mereka.

Akan tetapi ada sekelompok kecil di dalam lingkungan hitam tersebut, yang telah dimulai oleh tiga generasi sampai saat ini, yang mencoba memberikan pencerahan terhadap masyarakat di lingkungan tersebut melalui pendidikan agama Islam berupa shalat, puasa, membaca Al Qur'an beserta tajwidnya, do'a, dan fikih yang diikuti oleh beberapa jenjang usia, yaitu: anak-anak, remaja dan juga orang dewasa.

Kegiatan pendidikan agama Islam yang sudah berlangsung ini, perlu kiranya untuk di evaluasi dan dilihat apakah sudah memberikan pengaruh atau tidak terhadap kecerdasan spiritual peserta didiknya, khususnya peserta remaja. Untuk itu, penelitian yang akan diadakan ini meliputi kegiatan pendidikan agama Islam yang telah diberikan selama ini kepada khususnya anak-anak remaja yang tinggal di lingkungan tersebut, baik mereka yang tinggal bersama orang tuanya maupun tidak dengan keluarganya.

Pada pertengahan tahun 1990-an, Daniel Goleman menemukan kecerdasan emosional (Emotional Quotient) yang didasari oleh riset para neurosaintis tentang emosi manusia yang merupakan faktor penting dalam menentukan tingkat kecerdasan manusia. Menurut Goleman, EQ adalah kesanggupan untuk memperhitungkan, menyadari situasi yang terjadi, membaca emosi orang lain dan diri sendiri untuk kemudian bertindak dengan tepat. EQ berkaitan dengan mekanisme untuk merasa dan berfikir secara efektif, sehingga seorang individu diajarkan untuk berperilaku terhadap orang lain secara lebih cerdas dan bermanfaat. (Zohar, 2007). Pada akhir 1990-an, riset neurologis menunjukkan bahwa masih ada kecerdasan ketiga, yaitu kecerdasan untuk mengakses makna yang dalam, nilai-nilai fundamental, dan kesadaran akan adanya tujuan yang abadi dalam hidup manusia. kecerdasan 
tersebut disebut oleh Zohar (2007) sebagai 'kecerdasan spiritual' (Spiritual Intelligence/SI). Kecerdasan spitirual ini muncul dari beberapa pertanyaan-pertanyaan besar, misalnya mengapa manusia dilahirkan, apa makna hidup, apa yang hendak dicari, kemana tujuan hidup ini, hendak kemana pergi, apa manusia akan mati, apa yang akan terjadi setelah mati, dan sebagainya. Dengan kecerdasan spiritual inilah, menurut Zohar manusia dapat hidup secara sebenarnya, artinya lebih bermakna baik secara pribadi, sosial, maupun transendental (hubungan dengan Tuhan).

Selanjutnya, Zohar (2007) juga mengemukakan bahwa Kecerdasan spiritual telah melalui pembuktian ilmiah, bekerja berdasarkan sistim syaraf otak, yakni osilasi syaraf sinkron yang menyatukan data di seluruh bagian otak. Proses ini menyatukan, mengintegrasikan dan berpotensi mengubah materi yang timbul dari dua proses lainnya, yaitu IQ dan EQ, selanjutnya kecerdasan spiritual memfasilitasi suatu dialog antara akal dan emosi, antara pikiran dan tubuh, juga menyediakan titik tumpu bagi pertumbuhan dan perubahan dan menyediakan pusat pemberi makna yang aktif dan menyatu bagi diri.

Sepanjang rentang kehidupan dan perjalanan sejarah manusia, hampir setiap orang di mana pun dia berada, akan selalu ada pertanyaan mengenai dirinya, terlebih ketika membahas tentang sikap dan perilaku yang menghambat seseorang untuk meraih kecerdasan emosi dan spiritual, karena sikap dan perilaku sangat menentukan tingkat kecerdasan spiritual seseorang. Sikap dan perilaku penghambat itu adalah: diri tirani (nafs amarah), nafs tirani ini selalu berusaha untuk mendominasi dan mengendalikan pikiran serta tindakan kita,dan seringkali berhasil. Dikemukakan oleh Frager (2003), diri tirani disebut juga diri ke-aku-an (ananiyyah), adalah ego negative atau egoisme dan selfishness. Egoisme diartikan keakuan, dan selfishness diartikan sikap mementingkan diri sendiri, maka ananiyyah diartikan sikap dan perilaku yang selalu mementingkan diri sendiri dan berpusat pada keakuan yang konsekwensinya menyepelekan orang lain.(Nafis, 2006).

Berdasarkan definisi-definisi di atas, maka kecerdasan spiritual dapat diartikan: "Sebagai suatu pemahaman yang cepat dan tepat terhadap sesuatu yang immaterial yang ditandai dengan adanya makna, nilai-nilai, transendental, dalam hal ini dapat juga disebut sebagai landasan pemaknaan melalui berfungsinya IQ dan EQ, terhadap segala sesuatu yang dihadapi dalam kelangsungan kehidupan setiap manusia, dalam kaitannya dengan Allah, diri sendiri, orang lain, alam dan lingkungannya."

\subsection{MASALAH PENELITIAN}

Berdasarkan latar belakang masalah yang telah dikemukakan di atas, maka rumusan masalah dalam penelitian ini adalah: "Apakah terdapat pengaruh pendidikan Islam terhadap kecerdasan spiritual pada remaja yang tinggal di lingkungan Pekerja Seks Komersial (PSK) Tanah Abang Jakarta Pusat?"

\subsection{TUJUAN DAN MANFAAT}

Tujuan dari penelitian ini adalah:

1. Mengetahui apakah terdapat pengaruh pendidikan Islam yang selama ini sudah dilakukan pada remaja yang tinggal di lingkungan Pekerja Seks Komersial (PSK) Tanah Abang terhadap kecerdasan spiritual mereka.

2. Mengetahui seberapa besar sumbangan aspek pendidikan Islam yang sudah dilakukan di pengajian HURIN'IN terhadap kecerdasan spiritual pada remaja yang tinggal di lingkungan Pekerja Seks Komersial (PSK) Tanah Abang.

Adapun manfaat dari penelitian ini adalah:

1. Secara praktis : dapat memberikan informasi yang dapat membantu orang tua, pengajar, pemerintah, serta masyarakat untuk dapat memperhatikan lebih dalam lagi mengenai aspek pendidikan Islam dan keterkaitannya dengan kecerdasan spiritual remaja, yang merupakan penerus bangsa.

2. Secara teoritis : memberikan sumbangan pengetahuan tentang teori-teori yang berkaitan dengan pendidikan Islam dan kecerdasan spiritual.

\subsection{HASIL YANG DIHARAPKAN}

Penelitian ini diharapkan dapat memberikan kontribusi berupa masukan kepada orang tua sebagai sumber utama dan pertama yang akan memberikan pendidikan agama kepada anak-anak mereka, serta kepada para pengajar agama Islam di Pengajian HURIN'IN yang berada di lingkungan Pekerja Seks Komersial (PSK) Tanah Abang 
mengenai efektivitas proses belajar mengajar yang sudah mereka lakukan selama ini terhadap kecerdasan spiritual anak didik mereka.

\subsection{RUANG LINGKUP}

Penelitian ini akan membahas mengenai pendidikan Islam yang dilakukan di HURIN'IN Tanah Abang yang mencakup pembelajaran ibadah seperti shalat, puasa, membaca Al Qur'an beserta tajwidnya, do'a, dan fikih. Pembelajaran ini diberikan kepada remaja yang berusia 10 sampai 18 tahun, serta akan dilihat pengaruhnya terhadap kecerdasan spiritual menurut Swinton (2007) yang mencakup:

1. Meaning atau makna; memahami situasi kehidupan; mengetahui tujuan dari keberadaannya.

2. Value atau nilai, adalah keyakinan dan standard nilai yang dihargai

3. Transendence atau transenden, adalah pengalaman dan apresiasi terhadap sebuah dimensi dari luar diri; mengembangkan batasbatas diri.

4. Connecting atau hubungan, adalah menjalin hubungan dengan diri sendiri, orang lain, Allah sebagai kekuatan yang tertinggi dan lingkungan.

5. Becoming atau menjadi, adalah pengungkapan tentang kehidupan seseorang yang menuntut refleksi dan pengalaman; termasuk pengertian tentang siapa dirinya dan bagaimana dia mengetahuinya.

\section{KAJIAN TEORI}

Dalam Bab ini akan diuraikan kajian teori mengenai pendidikan Islam dan kecerdasan spiritual beserta aspek-aspeknya, remaja, dan Pekerja Seks Komersial (PSK).

\subsection{Pendidikan Islam}

\subsubsection{Pengertian Pendidikan Islam}

Salah satu istilah pendidikan dalam wacana keislaman yang lebih populer adalah tarbiyah. Menurut Muhammad al-Naquib al-Attas (dalam Mujib, Mudzakir, 2010:11), jika istilah tarbiyah diambil dari fi'il madhi-nya (rabbayani) maka ia memiliki arti memproduksi, mengasuh, menanggung, memberi makan, menumbuhkan, mengembangkan, memelihara, membesarkan dan menjinakkan.
Dalam pengertian tarbiyah ini, terdapat lima kata kunci yang dapat dianalisis:

a. Menyampaikan (al-tabligh)

b. Sesuatu (al-syay)

c. Sampai pada batas kesempurnaan (ila kamalihi)

d. Tahap demi tahap (syay' fa syay)

e. Sebatas pada kesanggupannya (bi hasbi isti'dadihi)

Dengan asumsi atas pengertian diatas, maka tugaspendidik dalam pendidikan Islam adalah transformasi kebudayaan kepada peserta didik, agar ia mampu memahami, menginternalisasikan dan menyampaikan kepada generasi berikutnya, melalui beberapa cara, diantaranya dengan ta'lim (pengajaran) yang mengarah pada aspek kognitif dan riyadhah yang diartikan dengan pengajaran dan pelatihan.

\subsubsection{Sumber dan Dasar Pendidikan Islam}

Sebagai sumber pendidikan Islam adalah semua acuan atau rujukan yang darinya memancarkan ilmu pengetahuan dan nilai-nilai yang akan ditransinternalisasikan dalam pendidikan Islam. Yang mana sumber ini dipergunakan untuk:

1. Mengarahkan tujuan pendidikan Islam yang ingin dicapai

2. Membingkai seluruh kurikulum yang dilakukan dalam proses belajar mengajar, yang di dalamnya termasuk materi, metode, media, sarana dan evaluasi

3. Menjadi standar dan tolok ukur dalam evaluasi, apakah kegiatan pendidikan telah tercapai dan sesuai dengan apa yang diharapkan atau belum. (Mujib, Mudzakir, 2010:31)

Menurut Sa'id Ismail Ali sebagaimana dikutip oleh Hasan Langgulung (dalam Mujib, Mudzakir: 2010), sumber pendidikan Islam terdiri atas enam macam, yaitu Al-Qur'an, As-Sunnah, kata-kata sahabat (madzhab shahabi), kemaslahatan umat/sosial (mashalil al-mursalah), tradisi atau adat kebiasaan masyarakat ('uruf), dan hasil pemikiran para ahli dalam Islam (ijtihad). Sumber tersebut didudukkan secara hierarkis, diawali dari sumber yang pertama (al-Qur'an) diikuti berurutan sampai yang keenam.

Untuk dasar pendidikan Islam yang merupakan landasan operasional sebagai dasar ideal/sumber pendidikan islam, menurut Hasan Langgulung, 
terdapat enam macam, yaitu historis, sosiologis, ekonomi, politik dan administrasi, psikologis dan filosofis, yang mana keenam dasar tersebutberpusat pada filosofis.

\subsubsection{Tugas dan Fungsi Pendidikan Islam}

Tugas pendidikan Islam senantiasa bersambung (kontinu) dan tanpa batas. Menurut Ibnu Taimiyah (dalam Mujib, Mudzakir, 2010:51), tugas pendidikan dalam islam pada hakikatnya tertumpu pada dua aspek, yaitu pendidikan tauhid dan pendidikan pengembangan tabiat peserta didik.

Fungsi pendidikan Islam adalah menyediakan segala fasilitas yang dapat memungkinkan tugastugas pendidikan Islam yang direncanakan tercapai dan berjalan dengan lancar, dalam hal ini penyediaan fasilitas ini berarti tujuan yang bersifat struktural dan institusional.

\subsubsection{Tujuan Pendidikan Islam}

Formulasi dari tujuan pendidikan Islam adalah upaya dalampencapaian tujan pendidikan harus dilaksanakan dengan semaksimal mungkin, walaupun pada kenyataannya manusia tidak mungkin menemukan kesempurnaan dalam berbagai hal. Menurut Abl a-Rahman Shaleh Abd Allah dalam bukunya, "Educational Theory, a Qur'anic Outlook" (dalam Mujib, Mudzakir 2010:78) menyatakan tujuan pendidikan Islam dapat diklasifikasikan menjadi empat dimensi, yaitu: tujuan pendidikan jasmani (al-ahdaf aljismiyah) adalah mempersiapkandiri manusia sebagai khalifah di bumi, melalui ketrampilan fisik; tujuan pendidikan rohani (al-ahdaf alruhaniyah) adalah meningkatkan jiwa dari kesetiaan yang hanya kepada Allah SWT., dan melaksanakan moralitas islami yang diteladani oleh Nabi SAW.

Maka kesimpulan dari tujuan pendidikan Islam adalah terbentuknya insan kamil yang didalamnya memiliki wawasn khalifah agar mampu menjalankan tugas - tugas kehambaan, kekhalifahan, dan pewaris Nabi,

\subsubsection{Pendidik Dalam Pendidikan Islam}

Pendidik atau disebut juga murabbi, mursyid atau disebut melalui gelarnya ustadz dan al syaikh adalah orang-orang yang bertanggung- jawab terhadap perkembangan peserta didiknya dengan upaya mengembangkan seluruh potensi peserta didik, baik potensi afektif (rasa), kognitif (cipta), maupun psikomotorik (karsa).

\subsubsection{Peserta Didik Dalam Pendidikan Islam}

Peserta didik dalam pendidikan Islam adalah individu yang sedang tumbuh dan berkembang, baik secara fisik, psikologis, sosial, dan religius dalam mengarungi kehidupan di dunia dan di akhirat kelak. Artinya bahwa peserta didik merupakan individu yang belum dewasa, karenanya memerlukan orang lain untk menjadikan dirinya dewasa. (Mujib, Mudzakir, 2010: 103).

\subsubsection{Kurikulum, Metode Dan Evaluasi Dalam Pendidikan Islam}

Isi kurikulum pendidikan Islam menurut Ibnu Khaldun membagi isi kurikulum menjadi dua tingkatan yaitu: tingkatan pemula (manhaj ibtida'i), di mana materi kurikulumnya difokuskan pada pembelajaran Al-Qur'an dan As-Sunnah. Metode dalam pedidikan Islam adalah media dari pendidikan, sesuai QS Al-Maidah:35, dan hakikat metode pendidikan islam adalah prosedur umum dalam penyampaian materi untuk mencapai tujuan pendidikan didasarkan atas asumsi tertentu tentang hakikat Islam sebagai suprasistem, yang harus dipahami oleh pendidik agar sesuai dengan tujuan pendidikan.

Evaluasi dalam pendidikan Islam adalah suatu kegiatan untuk menentukan taraf kemajuan suatu aktivitas di dalam pendidikan Islam, yang bertujuan untuk mengetahui kadar pemahaman peserta didik terhadap materi pelajaran, melatih keberanian dan mengajak peserta didik untuk memgimgat kembali materi yang telah diberikan, dan mengetahu tingkat perubahan perilakunya.

Sasaran evaluasi pendidikan Islam secara garis besarnya ada empat kemampuan, yaitu: (1) sikap dan pengalaman terhadap hubungan pribadinya dengan Tuhan; (2) sikap dan pengalaman terhadap arti hubungan dirinya dan masyarakat; (3) sikap dan pengalaman dirinya dan alam sekitarnya; (4) sikap dan pandangannya terhadap diri sendiri selaku hamba Allah, anggota masyarakat, serta selaku khalifah di muka bumi, berdasarkan prinsip-prinsip evaluasi pendidikan Islam, meliputi: prinsip kesinambungan; prinsip menyeluruh; prinsip objektivitas.

Pendidikan Islam dalam penelitian ini difokuskan pada tiga unsur pokok, yaitu: (1) akidah (iman), (2) ibadah (Islam), dan (3) Akhlak (ihsan). Ketiga 
unsur pokok inilah yang menjadi pilar agama Islam.

\section{Tinjauan tentang Akidah/Iman}

Iman, dalam bahasa Arab, berasal dari kata kerja amina-ya'manu yang berarti percaya. Iman menunjuk sikap batin yang terpusat di hati. Tetapi tidak hanya berhenti dengan percaya, melainkan mendorong orang yang memilikinya untuk melakukan ibadah dan amal yang terpuji. AlGhazali mensyaratkan tiga wujud iman; pembenaran di dalam hati, pengikraran dengan lidah, serta pengimplementasian dengan perbuatan (al-Iqtishaad fi al-I'tiqaad : 66). Dalam terminologi al-Qur'an, iman juga disebut dengan akidah.

Hal-hal yang wajib diimani oleh setiap muslim ada enam perkara. 1) Iman kepada Allah. 2) Iman kepada malaikat-malaikatNya. 3) Iman kepada kitab-kitabNya. 4) Iman kepada Rasul-rasulNya. 5) Iman kepada Hari Akhir. 6) Iman kepada ketentuan Allah.

Walaupun iman merupakan hal yang abstrak (tidak bisa ukur secara kasat mata), namun orang yang memiliki iman dapat diketahui dengan memperhatikan prilaku dan pandangan hidupnya. Misalnya, menyadari bahwa Allah Maha melihat segala perbuatannya, tidak meragukan syariat Allah, mempraktikkan keteladan Rasulullah, yakin akan akhirat, dan berintrospeksi diri seperti dengan mengingat kematian.

\section{Tinjauan tentang Ibadah/Islam}

Islam, dalam bahasa Arab, berasal dari kata kerja aslama-yuslimu yang berarti penyerahan kepada Allah SWT. penyerahan ini harus berwujud kepatuhan dan ketaatan untuk melaksanakan segala perintahNya, serta menjauhi apapun laranganNya.

Hal-hal yang menjadi pilar Islam terjewantah dalam lima perkara. 1) Mengucapkan dua kalimat syahadat, 2) Mendirikan shalat, 3) Menjalankan puasa Ramadhan, 4) Menunaikan zakat, dan 5) Pergi haji ke Baitullah bagi yang mampu.

Lima perkara tersebut yang menjadi indikator utama ibadah seorang muslim.

\section{Tinjauan tentang Akhlak/Ihsan}

Akhlak, dalam bahasa Arab, merupakan bentuk jama' dari khuluqun yang berarti budi pekerti. Menurut Ibnu Miskawaih, akhlak adalah keadaan jiwa seseorang yang mendorongnya untuk melakukan perbuatan-perbuatan tanpa melalui pertimbangan pikiran terlebih dahulu (Thohir Luth, 2007 : 115). Akhlak secara substansial merupakan sifat hati seseorang yang tercermin dalam prilaku.

Secara garis besar, akhlak dibagi menjadi dua klasifikasi: akhlak karimah (budi pekerti yang luhur) dan akhlak madzmumah (budi pekerti yang buruk). Keduanya terimplementasi dalam prilaku seseorang kepada Allah SWT., kepada orang lain, dan kepada dirinya sendiri (Kaelany HD., 2000).

\section{KECERDASAN SPIRITUAL}

Kecerdasan dalam bahasa Inggris disebut 'intelligence' dan bahasa Arab disebut 'al-dzaka'. Menurut Claparede and Stern, (dalam Sarwono, 2000:70), mengatakan intelligence adalah penyesuaian diri secara mental terhadap situasi atau kondisi baru. Selanjutnya David Wechsler, (dalam Sarwono, 2000:71) memberi definisi intelligence adalah kemampuan individu untuk berpikir dan bertindak secara terarah, serta mengolah dan menguasai lingkungan secara efektif. Kemampuan itu adalah kemampuan untuk mengolah lebih jauh lagi akan hal yang diamati. Dan Weintraub (1998), mendefinisikan Intelligence adalah kemampuan belajar atau memahami atau menghadapi situasi baru atau menantang (menguji) dan memunculkan atau merefleksikan penilaian yang baik atau pemikiran yang logis/terpercaya.

Spiritual, berasal dari kata 'spirit'. Beberapa arti menurut bahasa adalah satu zat atau makhluk immaterial, biasanya bersifat ketuhanan menurut aslinya, yang diberi sifat dari banyak ciri karakteristik manusia, selain itu diartikan sebagai kekuatan, tenaga, semangat vitalitas, energi atau moral dan juga motivasi. Sedangkan spiritual seperti diartikan diatas yang dikaitkan dengan ruh, semangat atau jiwa. Menurut Lines (2006:34), spirit berasal dari bahasa latin, spiritus, yang berarti "nafas" (yakni "nafas Allah"), dalam bahasa Indonesia disebut juga "ruh", dalam banyak tradisi ruh adalah sesuatu yang transenden dan memiliki persekutuan dengan manusia. Akhirnya Elkins, (dalam Lines, 2006:36) mendefinisikan spiritualitas adalah: "Spiritualitas, yang berasal dari bahasa Latin spiritus, yang berarti 'nafas dari kehidupan', adalah sebuah jalan kehidupan dan pengalamannya yang datang melalui kesadaran atas suatu dimensi yang transenden dan ditandai oleh beberapa nilai-nilai yang diidentifikasi dalam kaitannya dengan diri 
sendiri, orang lain, alam, kehidupan dan apapun yang dipertimbangkannya untuk menjadi sesuatu yang paling baik".

Definisi spiritualitas menurut Robinson (2008:36), dapat melibatkan tiga bagian, yaitu:

- Mengembangkan kesadaran dan appresiasi yang lain (termasuk diri, orang lain, kelompok, lingkungan dan jika memungkinkan, dewa)

- Mengembangkan kapasitas untuk merespon yang lain. Hal ini berkaitan dengan penerapan spiritualitas dalam praktek, mewujudkan spiritualitas dan dengan demikian berhubungan secara kontinyu dengan yang lain.

- Mengembangkan makna hidup yang tertinggi berdasarkan kesadaran dan apresiasi dari, dan respon terhadap, yang lain.

\section{Aspek-aspek Kecerdasan Spiritual}

Aspek-aspek kecerdasan spiritual yang dikemukakan oleh Swinton (2007:24), adalah:

1. Meaning atau makna, adalah sebagai makna ontologis yang signifikan dari kehidupan; memahami situasi kehidupan; mengetahui tujuan dari keberadaannya.(Gilbert, 2007:24)

2. Value atau nilai, adalah keyakinan dan standard nilai yang dihargai; berkaitan dengan kebenaran; keindahan; nilai; dari pikiran; perilaku atau obyek; sering berdiskusi sebagai 'nilai akhir'. (Gilbert, 2007:24)

3. Transendence atau transenden, adalah pengalaman dan apresiasi terhadap sebuah dimensi dari luar diri; mengembangkan batasbatas diri. (Gilbert, 2007:24).

4. Connecting atau hubungan, adalah menjalin hubungan dengan diri sendiri, orang lain, Allah sebagai kekuatan yang tertinggi dan lingkungan. (Gilbert, 2007 : 24), disebut, The Diamond of Self and Others.

5. Becoming atau menjadi, adalah pengungkapan tentang kehidupan seseorang yang menuntut refleksi dan pengalaman; termasuk pengertian tentang siapa dirinya dan bagaimana dia mengetahuinya.

\subsection{REMAJA}

Definisi tentang masa remaja memerlukan pertimbangan tentang usia dan pengaruh faktor sosial-sejarah. Remaja (adolescence) diartikan sebagai masa perkembangan transisi antara masa anak dan masa dewasa yang mencakup perubahan biologis, kognitif, dan sosial-emosional. Masa remaja dimulai kira-kira usia 10 sampai 13 tahun dan berakhir antara usia 18 dan 22 tahun (Santrock, 2003).

Remaja (adolescence) dalam bahasa latin diperoleh dari kata kerja adolescere yang berarti untuk tumbuh dan kembang menjadi dewasa (Steinberg, 1993:4). Lebih lanjut menjelaskan bahwa dalam pandangan masyarakat, periode remaja adalah waktu untuk tumbuh dan berkembang serta bergerak dari ketidak matangan masa kanak-kanak menuju ke arah kematangan pada usia dewasa. Periode remaja adalah periode transisi secara biologis, psikologis, sosiologis, dan ekonomi pada individu.

\subsection{PEKERJA SEKS KOMERSIAL (PSK)}

Pekerja Seks Komersial (PSK) adalah seseorang yang menjual jasanya untuk melakukan hubungan seksual untuk uang. Di Indonesia disebut juga dengan pelacur. Pelacur adalah profesi yang menjual jasa untuk memuaskan kebutuhan seksual pelanggan. Biasanya pelayanan ini dalam bentuk menyewakan tubuhnya. Di kalangan masyarakat Indonesia, pelacuran dipandang negatif, dan mereka yang menyewakan atau menjual tubuhnya sering dianggap sebagai sampah masyarakat. Istilah pelacur sering diperhalus dengan pekerja seks komersial, wanita tuna susila, istilah lain yang juga mengacu kepada layanan seks komersial. Khusus laki-laki, digunakan istilah gigolo.

\section{METODOLOGI PENELITIAN}

\subsection{JENIS PENELITIAN}

Penelitian ini dilakukan dengan metode kuantitatif yaitu penelitian yang datanya berbentuk angka atau data kualitatif yang (Sugiyono, 2009). Jenis penelitiannya berupa penelitian survei. Penelitian survei merupakan penelitian yang menggunakan kuesioner sebagai instrumen penelitian. Kuesioner merupakan lembaran yang berisi beberapa pernyataan dengan struktur yang baku (Prasetyo \& Miftahul Jannah, 2005).

\subsection{SUBYEK PENELITIAN}


Subyek dalam penelitian ini adalah 20 orang santri di Pengajian HURIN'IN Tanah Abang yang dalam usia perkembangan remaja yaitu 10 sampai 18 tahun.

\subsection{PROSEDUR PENELITIAN}

Secara garis besar penelitian ini dilakukan dalam 3 tahapan, yaitu:

a. Persiapan penelitian

Hal-hal yang dilakukan dalam persiapan penelitian ini adalah membuat alat ukur berupa kuesioner yang berisi pendidikan Islam yang telah dilakukan di pengajian HURIN'IN dan kuesioner mengenai kecerdasan spiritual. Hal lain yang perlu dipersiapkan adalah menghubungi pihak-pihak yang terkait, yaitu pimpinan pengajian Hurin'in yaitu Ustadz Ramli Izhaque dan santri pengajian yang akan menjadi subjek dalam penelitian ini.

b. Pelaksanaan penelitian

Penelitian ini dilaksanakan di Tanah Abang Jakarta Pusat pada bulan Maret sampai Juli 2012.

c. Pelaporan penelitian

Tahap ini adalah tahap akhir dengan melakukan pengolahan data dan membuat hasil penelitian dalam bentuk laporan.

\subsection{TEKNIK PENGUMPULAN DATA}

Pengumpulan data sangat diperlukan dalam penelitian karena mempengaruhi kualitas data hasil penelitian. Pengumpulan data data dalam penelitian ini dilakukan dengan cara pengambilan angket (kuesioner). Kuesioner merupakan teknik pengumpulan data yang dilakukan dengan cara memberi seperangkat pertanyaan atau pernyataan tertulis kepada responden untuk dijawab. (Sugiyono, 2009).

Keunggulan dalam angket yaitu angket dapat digunakan untuk mengumpulkan data dari sejumlah besar responden yang menjadi sampel, responden lebih leluasa menjawab pertanyaan serta tidak dipengaruhi oleh sikap mental hubungan peneliti dan responden. Disamping itu jawaban dapat dipikirkan masak-masak terlebih dahulu dan data yang dikumpulkan lebih mudah dianalisis karena pertanyaan yang diajukan kepada setiap responden sama.(Gulow,2005)

\subsection{INSTRUMEN PENELITIAN}

Instrument penelitian digunakan untuk melakukan pengukuran dengan tujuan menghasilkan data kuantitatif yang akurat, maka setiap instrument harus mempunyai skala. (Sugiyono,2009).

Skala pengukuran Instrumen yang digunakan dalam penelitian ini adalah dengan model skala Likert. Menurut Sugiyono (2009: 107) skala Likert digunakan untuk mengukur sikap, pendapat, dan persepsi seseorang atau sekelompok orang tentang fenomena sosial. Dengan skala Likert, maka variabel yang akan diukur dijabarkan menjadi indikator variabel. Kemudian indikator tersebut dijadikan sebagai titik tolak untuk menyusun itemitem instrumen yang dapat berupa pertanyaan atau pernyataan yang terdiri dari pertanyaan atau pernyataan yang bersifat positif (favorable) dan negatif (unfavorable) dengan sistem penilaian skala sebagai berikut:

Tabel 1. Penilaian Skala Likert

\begin{tabular}{|c|c|c|}
\hline $\begin{array}{c}\text { Alternatif } \\
\text { Jawaban }\end{array}$ & Favorable & $\begin{array}{c}\text { Unfavorab } \\
\text { le }\end{array}$ \\
\hline $\begin{array}{c}\text { Sangat } \\
\text { Sesuai (SS) }\end{array}$ & 4 & 1 \\
\hline Sesuai (S) & 3 & 2 \\
\hline $\begin{array}{c}\text { Tidak Sesuai } \\
\text { (TS) }\end{array}$ & 2 & 3 \\
\hline $\begin{array}{c}\text { Sangat Tidak } \\
\text { Sesuai (STS) }\end{array}$ & 1 & 4 \\
\hline
\end{tabular}

Terdapat 2 skala yang digunakan dalam penelitian ini, yaitu skala pendidikan Islam dan skala kecerdasan spiritual.

\subsection{ANALISIS DATA}

Pengolahan data hasil penelitian menggunakan analisis statistik dengan program SPSS 20.0 for windows. Metode analisis yang digunakan dalam penelitian ini adalah metode statistik regresi linear sederhana. Regresi linear sederhana didasarkan pada hubungan fungsional ataupun kausal antara satu variabel independen dengan satu variabel dependen (Sugiono, 2009). 


\section{HASIL PENELITIAN}

\subsection{Deskripsi Data}

\subsubsection{Gambaran Umum Subjek Penelitian}

Penelitian ini dilakukan pada siswa - siswi Pengajian Hurin'in yang tinggal di lingkungan Pekerja Seks Komersial (PSK) Tanah Abang, usia 10 sampai 18 tahun, yang terdiri dari 18 orang perempuan dan 12 orang laki-laki.

Lokasi pengajian Hurin'in ini berdekatan dengan lokasi prostitusi. Berdiri pada tahun 1970 sebagai "Pengajian Lekar", yaitu serupa dengan pengajian zaman dulu yang identik dengan "turutan" dan "sarung".

Sejak pendiriannya hingga saat ini, Hurin'in sudah berganti kepemimpinan sebanyak 4 kali. Pengajian ini pertama kali dipimpin oleh paman dari ustadz Ramli Izhaque, lalu ayah dan kakaknya. Saat ini dipimpin oleh ustadz Ramli Izhaque sendiri. Sejak tahun 1998, kegiatan di Hurin'in tidak hanya berupa pengajian saja, melainkan mulai berubah menjadi Pusat Belajar Pendidikan dan Kemanusiaan. Seiring dengan perubahan tersebut, maka sisiwa-siswi Hurin'in tidak hanya belajar mengaji, melainkan juga mendapat pelajaran ekstra kurikuler seperti teater, marawis, pencak silat dan paduan suara.

Pengajian Hurin'in, juga menekankan tentang "3S", yaitu, Sholat, Surat (Mengaji) dan Silat. Pada tanggal 16 juli 2010, melalui pengesahan notaris, Hurin'in resmi memiliki akta pendirian sebagai Yayasan Pusat Studi Pendidikan dan Kemanusiaan.

\subsection{Hasil Uji Persyaratan Instrumen}

Untuk mengetahui apakah item-item yang digunakan telah mengukur apa yang seharusnya diukur dan konsistensinya dapat diandalkan, maka dilakukan uji validitas dan reliabilitas pada instrument yang digunakan, yaitu skala pendidikan Islam dan kecerdasan emosional.

\subsubsection{Uji Validitas}

Valid artinya mengukur dengan tepat sesuatu yang ingin diukur dan seberapa jauh alat ukur itu memberi sifat ketelitian sehingga dapat menunjukkan gejala yang diukur dengan sebenarnya. Sedangkan Validitas adalah kecermatan dan ketepatan skala dalam menjalankan fungsi ukurnya, sejauh mana skala tersebut mampu mengukur apa yang ingin diukur (Azwar , 2010). Untuk menguji validitas aitem digunakan program SPSS 20.0 For Windows dengan menggunakan analisis Bivariate Pearson (korelasi product moment) dengan cara mengkorelasikan masing-masing skor item dengan skor total, adapun rumus korelasi Bivariate Pearson product moment.

Dari hasil analisis uji validitas item pada skala Pendidikan Islam didapat nilai korelasi antara skor item dengan skor total. Nilai $r$ table pada taraf signifikansi 0,05 dengan uji 2 sisi dan jumlah data $(\mathrm{n})=30$ adalah 0,361 . Berdasarkan perbandingan antara nilai korelasi masing-masing item dengan nilai $r$ table diperoleh 8 item yaitu item $1,6,8,10$, $16,18,23$, dan 30 yang nilainya kurang dari 0,361 . Maka dapat disimpulkan bahwa item-item tersebut tidak berkorelasi signifikan dengan skor total (tidak valid), sehingga harus dikeluarkan. Sedangkan pada item-item lainnya nilai korelasinya lebih dari 0,361 dapat disimpulkan bahwa butir instrument tersebut valid. Jadi pada skala pendidikan Islam dari 30 item yang diujicobakan, terdapat 22 item yang valid dan 8 item gugur karena mempunyai validitas kurang dari 0,361 .

Kemudian dari hasil analisis uji validitas item pada skala kecerdasan spiritual didapat nilai korelasi antara skor item dengan skor total. Nilai $r$ table pada taraf signifikansi 0,05 dengan uji 2 sisi dan jumlah data $(\mathrm{n})=30$ adalah 0,361 . Berdasarkan perbandingan antara nilai korelasi masing-masing item dengan nilai $r$ table diperoleh 5 item yang nilainya kurang dari 0,361 , yaitu item $35,36,42$, 49, dan 50. Maka dapat disimpulkan bahwa item $35,36,42,49$, dan 50 tidak berkorelasi signifikan dengan skor total (tidak valid), sehingga harus dikeluarkan. Sedangkan pada item-item lainnya nilai korelasinya lebih dari 0,361 dapat disimpulkan bahwa butir instrument tersebut valid. Dari 20 item yang diujicobakan pada skala kecerdasan spiritual, terdapat 15 item yang valid dan 5 item gugur karena mempunyai validitas kurang dari 0,361 .

\subsubsection{Uji Reliabilitas}

Alat ukur yang telah dibuat sebelumnya dilakukan uji reliabilitas dengan menggunakan program SPSS 20.0 For Windows dengan menggunakan teknik Alpha Cronbach dan dikenakan kepada skala pengukuran yang memenuhi syarat kesahihan saja. Uji reliabilitas digunakan untuk mengetahui konsistensi dari alat ukur serta untuk 
mengetahui apakah alat pengukur yang digunakan dapat diandalkan dan tetap konsisten jika pengukuran tersebut diulang.

Setelah melakukan uji validitas pada skala pendidikan Islam dan kecerdasan emosional, dan memperoleh item-item yang valid, kemudian dilakukan pengujian reliabilitas.

Hasil pengujian reliabilitas dengan menggunakan metode Alpha Cronbach pada skala pendidikan Islam adalah sebesar 0,869. Sedangkan nilai $r$ kritis (uji 2 sisi) pada signifikansi 0,05 dengan jumlah data $(n)=30$ didapat nilai 0,361 . Karena nilainya lebih dari 0,361 maka dapat disimpulkan bahwa butir-butir instrument penelitian pada skala pendidikan Islam tersebut reliable.

Kemudian analisis reliabilitas untuk skala kecerdasan spiritual diperoleh hasil sebesar 0,891. Sedangkan nilai $r$ kritis (uji 2 sisi) pada signifikansi 0,05 dengan jumlah data $(n)=30$ didapat nilai 0,361 . Karena nilainya lebih dari 0,361 maka dapat disimpulkan bahwa butir-butir instrument penelitian pada skala kecerdasan spiritual tersebut reliable.

Kemudian hasil tersebut juga dapat disesuaikan dengan kaidah yang berlaku untuk mengetahui tinggi rendahnya reliabilitas alat tes berdasarkan rumusan ktiteria koefisien reliabilitas menurut Guilford sebagai berikut :

\section{Tabel 6. Kaidah Reliabilitas Menurut Guilford}

\begin{tabular}{|c|c|}
\hline Kriteria & Koefisien Reliabilitas \\
\hline Sangat Reliabel & $>0.9$ \\
\hline Reliabel & $0.7-0.9$ \\
\hline Cukup Reliabel & $0.4-0.7$ \\
\hline $\begin{array}{c}\text { Kurang } \\
\text { Reliabel }\end{array}$ & $0.2-0.4$ \\
\hline Tidak Reliabel & $<0.2$ \\
\hline
\end{tabular}

Dengan mengacu pada kaidah Guilford, skala pendidikan Islam dan kecerdasan spiritual memiliki koefisien reliabilitas dengan kriteria reliabel, maka skala tersebut dapat digunakan serta dapat dikatakan memiliki reliabilitas.

\subsection{Pengujian Persyaratan Analisis}

Pengujian persyaratan analisis yang dimaksud adalah pengujian asumsi dasar yang digunakan sebagai persyaratan yang harus terpenuhi sebelum melakukan pengujian hipotesis. Karena pengujian hipotesis pada penelitian ini menggunakan regresi linear sederhana, maka persyaratan analisisnya berupa pengujian normalitas dan uji linearitas.

\section{Pengujian Normalitas}

Uji normalitas digunakan untuk mengetahui apakah populasi data berdistribusi normal atau tidak. Uji ini biasanya digunakan untuk mengukur data berskala ordinal, interval, ataupun rasio. Jika analisis menggunakan metode parametrik, maka persyaratan normalitas harus terpenuhi, yaitu data berasal dari distribusi yang normal (Dwi Priyatno, 2008: 28).

Distribusi frekuensi akan mendekati normal apabila distribusi populasi tidak menyimpang dan jumlah sampel (N) tidak kecil yakni lebih dari 30 (Guilford, 1981). Dengan demikian data penelitian ini yang berjumlah 30 dianggap telah memenuhi syarat dan berdistribusi normal.

\section{Uji Linearitas}

Uji linearitas bertujuan untuk mengetahui apakah dua variabel mempunyai hubungan yang linier atau tidak secara signifikan. Uji ini digunakan sebagai prasyarat dalam analisis regresi linear. Pengujian pada SPSS dengan menggunakan Test for Linearity pada taraf signifikansi 0,05. Dua variabel dikatakan mempunyai hubungan yang linear bila signifikansi (Linearity) kurang dari 0,05 (Dwi Priyatno, 2008: 36).

Dari output SPSS 20.0 for windows diperoleh nilai signifikansi pada linearity sebesar 0,000. Karena signifikansi kurang dari 0,05 maka dapat disimpulkan bahwa antara variable Pendidikan Islam dan Kecerdasan Spiritual terdapat hubungan yang linear.

\subsection{Pengujian Hipotesis}

Setelah semua uji persyaratan analisis dilakukan, dan hasilnya dari semua skor tiap variabel penelitian memenuhi persyaratan untuk dilakukan pengujian statistik lebih lanjut, maka selanjutnya dilaksanakan pengujian hipotesis. Pengujian hipotesis ini dilakukan dengan menggunakan metode statistik yang meliputi pengujian regresi linear sederhana. Berikut ini akan disajikan 
pembahasan hasil pengujian terhadap hipotesis penelitian dengan menggunakan uji regresi linear sederhana.

\section{Uji Regresi Linear Sederhana}

Analisis regresi linier sederhana digunakan untuk mengetahui pengaruh secara linier antara variabel Pendidikan Islam (X) terhadap Kecerdasan Spiritual (Y).

Persamaan regresi yang diperoleh berdasarkan hasil output adalah sebagai berikut:

$$
\begin{aligned}
& \hat{Y}=a+b X \\
& \hat{Y}=25,224+0,398 X
\end{aligned}
$$

Berdasarkan hasil pengolahan SPSS 20.0 for windows diperoleh konstanta sebesar 25,224 yang artinya jika variabel pendidikan Islam dianggap konstan, maka variabel kecerdasan spiritual adalah sebesar 0,398. Kemudian untuk nilai koefisien regresi variable pendidikan $(X)$ sebesar 0,398; artinya jika nilai pendidikan Islam naik sebesar satu satuan, maka kecerdasan spiritual akan naik sebesar 0,398. Koefisien bernilai positif artinya terjadi hubungan positif antara pendidikan Islam dengan kecerdasan spiritual, semakin baik pendidikan Islam yang dilakukan maka semakin meningkatkan kecerdasan spiritual.

\section{Uji Koefiensi Regresi Sederhana (uji t)}

Uji ini digunakan untuk mengetahui apakah variabel independen $(\mathrm{X})$ berpengaruh secara signifikan terhadap variabel dependen (Y). Signifikan berarti pengaruh yang terjadi dapat berlaku untuk populasi (dapat digeneralisasikan). Rumus $\mathrm{t}$ hitung pada analisis regresi adalah sebagai berikut:

\section{Keterangan:}

$$
\text { thitung }=\frac{r \sqrt{n-2}}{\sqrt{1-r^{2}}}
$$

$$
\begin{array}{ll}
\mathrm{r} & \text { : Koefisien korelasi sederhana } \\
\mathrm{n} & \text { : Jumlah data }
\end{array}
$$

Dari hasil output analisis regresi dapat diketahui nilai $\mathrm{T}$ hitung 4,815. Tingkat signifikansi yang digunakan adalah a $=5 \%$ atau 0,05 yang merupakan ukuran standar yang sering digunakan dalam penelitian. Kemudian kita dapat mencari nilai $\mathrm{T}$ Tabel pada tabel distribusi $\mathrm{t} \mathrm{a}=5 \%: 2=$ $2,5 \%$ (uji 2 sisi), dengan derajat kebebasan $(\mathrm{df})=\mathrm{n}$ $-\mathrm{k}-1=30-1-1=28(\mathrm{n}=$ jumlah kasus, $\mathrm{k}=$ jumlah variable independen). Dengan pengujian 2 sisi (signifikansi 0,025), diperoleh hasil untuk T Tabel sebesar 2,048.

Kriteria untuk menjawab hipotesis adalah Ho diterima jika jika $-\mathrm{t}$ tabel $\leq \mathrm{t}$ hitung $\leq \mathrm{t}$ tabel, dan Ho ditolak jika $\mathrm{t}$ hitung $>\mathrm{t}$ tabel. Dan hasilnya menunjukkan bahwa $\mathrm{t}$ hitung $>\mathrm{t}$ tabel $(4,815>$ 2,048).

Kesimpulannya adalah karena nilai $\mathrm{t}$ hitung $>\mathrm{t}$ tabel $(4,815>2,048)$ maka Ho ditolak; artinya bahwa ada pengaruh secara signifikan antara pendidikan Islam dengan kecerdasan spiritual. Jadi dalam penelitian ini dapat disimpulkan bahwa pendidikan Islam yang dilakukan selama ini di Pengajian Hurin'in berpengaruh terhadap kecerdasan spiritual pada remaja santri Hurin'in yang tinggal di lingkungan Pekerja Seks Komersial (PSK) Tanah Abang.

\section{Koefisien Determinasi}

Koefisien determinasi dilakukan untuk mengetahui seberapa besar kontribusi variable pendidikan Islam terhadap kecerdasan spiritual pada remaja yang tinggal di lingkungan Pekerja Seks Komersial (PSK) Tanah Abang. Hasilnya dijelaskan pada tabel berikut ini:

\section{Tabel 7. Hasil Koefisien Determinasi Pendidikan Islam Terhadap Kecerdasan Spiritual}

\begin{tabular}{|r|r|}
\multicolumn{1}{|c|}{ Model Summary $^{\mathbf{b}}$} \\
\hline R Square & Adjusted R Square \\
\hline .453 & .433 \\
\hline a. Predictors: (Constant), Pendidikan Islam \\
b. Dependent Variable: Kecerdasan Spiritual
\end{tabular}

Koefisien determinasi ( $\left.\mathrm{R}_{\text {Square }}\right)$ digunakan sebagai alat analisis untuk menunjukkan seberapa besar kontribusi dari variabel pendidikan Islam terhadap kecerdasan spiritual. Dari tabel diatas diketahui bahwa nilai $\mathrm{R}_{\text {Square }}$ sebesar 0,453 atau $45,3 \%$. Hal ini menunjukkan bahwa persentase sumbangan pengaruh variabel independen (pendidikan Islam) terhadap variabel dependen (kecerdasan spiritual) sebesar $45,3 \%$. Sedangkan sisanya sebesar $54,7 \%$ dipengaruhi oleh variabel lain yang tidak dibahas dalam penelitian ini.

\section{Interpretasi Data}

Berdasarkan hasil pengolahan SPSS 20.0 for windows diperoleh konstanta sebesar 25,224 yang artinya jika variabel pendidikan Islam dianggap 
konstan, maka variabel kecerdasan spiritual adalah sebesar 0,398. Kemudian untuk nilai koefisien regresi variable pendidikan (X) sebesar 0,398; artinya jika nilai pendidikan Islam naik sebesar satu satuan, maka kecerdasan spiritual akan naik sebesar 0,398. Koefisien bernilai positif artinya terjadi hubungan positif antara pendidikan Islam dengan kecerdasan spiritual. Nilai signifikansi 0,000 lebih kecil dari $0,05(0,000<0,05)$, maka dapat disimpulkan bahwa ada pengaruh yang signifikan antara pendidikan Islam terhadap kecerdasan spiritual. Maka hipotesis penelitian menerima Ha dan menolak Ho. Kemudian juga diperoleh nilai $\mathrm{t}$ hitung $>\mathrm{t}$ tabel $(4,815>2,048)$ maka Ho ditolak; artinya ada pengaruh secara signifikan antara pendidikan Islam dengan kecerdasan spiritual. Jadi dalam penelitian ini dapat disimpulkan bahwa pendidikan Islam yang dilakukan selama ini di Pengajian Hurin'in berpengaruh terhadap kecerdasan spiritual pada remaja santri Hurin' in yang tinggal di lingkungan Pekerja Seks Komersial (PSK) Tanah Abang.

Koefisien determinasi $\left(\mathrm{R}_{\text {Square }}\right)$ digunakan sebagai alat analisis untuk menunjukkan besarnya kontribusi pengaruh dari variabel penanaman nilainilai religiusitas terhadap kecerdasan emosional pada remaja. Dalam hal ini diperoleh $\left(\mathrm{R}_{\text {Square }}\right)$ sebesar 0,453 yang menunjukkan bahwa $45,3 \%$ variabel kecerdasan spiritual remaja yang tinggal di lingkungan Pekerja Seks Komersial (PSK) dipengaruhi oleh pendidikan Islam, sisanya 54,7\% dipengaruhi oleh faktor lainnya yang tidak dibahas di dalam penelitian ini.

\section{KESIMPULAN DAN SARAN}

\subsection{Kesimpulan}

Berdasarkan seluruh analisis data serta pengujian hipotesa yang telah dilakukan terhadap variabel pendidikan Islam dan kecerdasan spiritual, maka yang dapat disimpulkan dalam penelitian ini adalah sebagai berikut :

1. Terdapat pengaruh yang signifikan antara pendidikan Islam yang dilakukan di Pengajian Hurin'in terhadap kecerdasan spiritual remaja santri Hurin'in yang tinggal di lingkungan Pekerja Seks Komersial (PSK) Tanah Abang Jakarta Pusat. Hal ini dapat dilihat dari nilai signifikansi 0,000 lebih kecil dari $0,05(0,000<0,05)$ dan nilai t hitung > t tabel $(4,815>2,048)$, maka Ho ditolak; artinya ada pengaruh secara signifikan antara pendidikan Islam dengan kecerdasan spiritual.

2. $45,3 \%$ variabel kecerdasan spiritual remaja yang tinggal di lingkungan Pekerja Seks Komersial (PSK) dipengaruhi oleh pendidikan Islam, sisanya $54,7 \%$ dipengaruhi oleh faktor lainnya yang tidak dibahas di dalam penelitian ini.

\subsection{Saran}

Berdasarkan hasil penelitian, maka saran-saran untuk perbaikan dan pengembangan dalam penelitian ini adalah :

\subsubsection{Saran Teoritis}

Penelitian selanjutnya dapat mempertimbangkan variabel lainnya, seperti pengaruh kepedulian sosial, nilai-nilai (values), pola asuh orang tua, atau pengaruh faktor-faktor lainnya terhadap keserdasan spiritual.

\subsubsection{Saran Metodologis}

1. Penelitian selanjutnya diharapkan dapat diperkuat dengan menambahkan pendekatan kualitatif agar mendapatkan gambaran mengenai proses belajar mengajar yang dilakukan di pengajian Hurin'in beserta teknik-tekniknya dan gambaran kecerdasan spiritual secara lebih jelas.

2. Sebaiknya untuk penelitian selanjutnya dapat menggunakan sampel dengan karakteristik yang lebih beragam dengan jumlah yang lebih besar agar dapat digeneralisasi.

\subsubsection{Saran Praktis}

Penelitian ini menunjukkan bahwa terdapat pengaruh pendidikan Islam yang sudah dilakukan di Pengajian Hurin'in selama ini memberikan pengaruh terhadap kecerdasan spiritual santrisantri remaja yang tinggal di lingkungan Pekerja Seks Komersial (PSK) Tanah Abang. Namun perlu kiranya Pengajian Hurin'in melakukan perbaikan dari segi metode dan teknik-teknik pengajaran yang lebih beragam, tenaga pengajar yang berkualitas, serta sarana dan prasarana yang lebih memadai.

\section{DAFTAR PUSTAKA}


[1] Baharuddin \& Nur Esa Wahyuni., 2007., Teori Belajar dan Pembelajaran., Jogjakarta: Ar-ruzz Media.

[2] Coyte, M.E., Gilbert, P and Nicholls, V., 2007., Spirituallity, Values and Mental Health, Jewel for the Journey. UK: Jesica Kingsley Publisher.

[3] Djaafar, Tengku Zahara., 2001., Kontribusi Strategi Pembelajaran Terhadap Hasil Belajar., Jakarta: Universitas Negeri Padang.

[4] Frager, R., 2003., Hati, Diri \& Jiwa, Psikologi Sufi untuk Transformasi., Jakarta: PT Serambi Ilmu semesta.

[5] Guilford, J.P. \& Benyamin Fruchter. (1981). Fundamental Statistics in Psychology and Education. Tokyo: Kogakusha Mc Graw Hill Book

[6] Hurlock.,Elizabeth 1980., Developmental Psychology, A Life Span Approach., McGraw-Hill.

[7] Lines, D., 2006., Spirituallity in Counselling and Psychotheraphy., London: Sage Publications.

[8] Mujib, Abdul \& Jusuf, Mudzakkir., 2006., Ilmu Pendidikan Islam., Jakarta: Kencana Prenada Media.
[9] Mujib, Abdul \& Muhaimin \& Jusuf, Mudzakkir., 2007., Kawasan dan Wawasan Study Islam., Jakarta: Prenada Media.

[10] Priyato, Dwi., 2008., Mandiri Belajar SPSS (Statistical Product and Service Solution) untuk Analisis Data dan Uji Statistik., Yogyakarta: Media Kom.

[11] Robinson, S., 2008., Spirituallity, Ethics and Care., UK: Jessica Kingsley Publishers.

[12] Saifuddin, Azwar., 2010. Penyusunan Skala Psikologi., Yogyakarta: Pustaka Pelajar.

[13] Santrock, John W., 2003., Adolescence Perkembangan Remaja., Jakarta: Erlangga

[14] Sarwono, S.W., 2000., Pengantar Umum Psikologi., Jakarta: Bulan Bintang. Sugiyono., 2009., Metode Penelitian Administrasi., Bandung: Alfabeta.

[15] Syamsuddin Makmun, H. Abin., 2005., Psikologi Kependidikan., Bandung: PT. Remaja Rosdakarya.

[16] Weintraub, S., 19980., The Hidden Intelligence - Innovation Through Intution., Woburn: Butterworth Heinemann

[17] Zohar, Dannah. And Marshall, Ian., 2007., SQ: Kecerdasan Spiritual., (Helmi Mustofa, Penerjemah). (Cet. XI.), Bandung: Penerbit Mizan. 